\title{
Vurdering av troverdighet: Hva sier forskningen anno 2020?
}

\author{
Svein Magnussen og Ulf Stridbeck
}

Svein Magnussen er professor emeritus, Psykologisk institutt, Universitetet i Oslo, har de siste 20 år forsket på vitnepsykologiske problemstillinger. Mottager av NFRs pris for fremragende forskning, Møbius, 2001, og Fridtjof Nansens belønning for fremragende forskning (DNVA) 2007. E-post: s.j.magnussen@psykologi.uio.no

Ulf Stridbeck er professor emeritus, Institutt for offentlig rett, Universitetet i Oslo. Er fil.kand. Universitetet i Göteborg 1981, jur.kand. Lunds Universitet 1981, jur. dr. Lunds universitet 1992. Professor dr. juris ved Universitetet i Oslo 1997-2019, med ansvar for strafferett. Har de seneste 20 år publisert fagartikler innenfor juss og psykologi. Er siden 2004 styremedlem i Nordic Network for research in Psychology and Law.

E-post: ulf.stridbeck@jus.uio.no

\section{Sammendrag}

Artikkelen gir en oppdatert fremstilling av forskningen på løgn og løgnavsløring i et rettslig og samfunnsmessig perspektiv. Forskningen er klar: Det foreligger intet alternativ til etterforskning. Det er så og si umulig å avsløre løgn og uriktige forklaringer på grunnlag av hvordan vitner fremstår; det er heller ikke mulig på grunnlag av atferdsobservasjon å avsløre personer som seiler under falsk flagg i dagliglivet, eller personer med kriminelle hensikter. Artikkelen advarer mot kurs og programmer som tilbyr enkle oppskrifter på løgnavsløring. ${ }^{1}$

Nøkkelord: vitner - avsløring av løgn - kroppsspråk - atferds-observasjoner - psykologiske myter - empirisk forskning

\footnotetext{
${ }^{1}$ Takk til anonym fagfelle for gode innspill.
} 
He who has eyes to see and ears to hear may convince himself that no mortal can keep a secret. If his lips are silent, he chatters with his fingertips; betrayal oozes out of him at every pore.

Sigmund Freud ${ }^{2}$

\section{Innledning}

Folk lyver. Vi lyver i dagliglivet, vi lyver i jobbsammenheng, vi lyver i det offentlige rom og vi lyver i retten. Direkte løgn og mer eller mindre subtile omgåelser av sannheten er realiteter vi må forholde oss til. Forskning forteller at de aller fleste av oss lyver i alle fall et par ganger i uken i omgang med andre, noen av oss er mer kreative løgnere og lyver hver dag, et fåtall av oss endatil flere ganger om dagen. Løgn er et mangefasettert fenomen og løgn er heller ikke utelukkende negativt. Enkelte ganger må vi omgå sannheten for ikke å såre andre, vi gir komplimenter og positive tilbakemeldinger vi egentlig ikke mener for å støtte og oppmuntre, og det hender vi tyr til en nødløgn for å redde en pinlig situasjon. Løgn kan fungere som olje i det sosiale liv, å si den absolutte sannhet til enhver tid ville være en sosial katastrofe. ${ }^{3}$ Men det er i to sammenhenger hvor løgn er uakseptabelt: Politikere og andre offentlige personer som uttaler seg i det offentlige rom skal ikke omgå sannheten, og i retten forventes det sannferdige forklaringer. ${ }^{4}$ Det vil si, den mistenkte kan lyve, hun kan underslå og fordreie informasjon til

\footnotetext{
${ }^{2}$ S. Freud, Dora: An Analysis of a Case of Hysteria, i Collected Papers. New York: Basic Books, 1959.

${ }^{3}$ Nyere studier av løgn i dagliglivet er gjennomført i England, Nederland, Tyskland og USA, K. B., Serota, T. R. Levine og F. J. Boster, The prevalence of lying in America. Three studies of self-reported lies. Human Communication Research, 36,s. 2-25, 2010; K. B. Serota og T. R. Levine, A few prolific liars: Variation in the prevalence if lying. Journal of Language and Social Psychology, 34, s. 138-157, 2015; R. Halevy, S. Shalvi og B. Verschuere, Being honest about dishonesty: Correlating self-reports and actual lying. Human Communication Research, 40, s. 54-72, 2014. De fleste selvrapporterte Iøgner i dagliglivet er varianter av hvite løgner, under $10 \%$ er alvorlige løgner, direkte fabrikasjoner, B. L. Verigin, E. H. Meijer, G. Bogaard og A. Vrij, Lie prevalence, lie characteristics and strategies of self-reported good liars. PLOS ONE 14, e0225566, 2019.

${ }^{4}$ Hyppigheten av løgner og type løgner i det politiske liv og i retten vet vi mindre om, men løgn i alle sine subtile varianter har alltid vært en del av det politiske liv og fortsetter å være det, som normale mediekonsumenter for
} 
egen gunst uten at det får konsekvenser for straffeutmålingen ${ }^{5}$, men vitner pålegges å fortelle den fulle sannhet slik vitnet oppfattet den. ${ }^{6}$ Og løgn i retten - uriktige forklaringer - er forbundet med strafferettslig ansvar. ${ }^{7}$

I en vitnepsykologisk sammenheng har forskningen på avsløring av løgn og vurdering av troverdighet under etterforskning og i retten fokusert på ikke-verbal kommunikasjon, på atferden («kroppsspråket») som ledsager forklaringer og på språkets ikke-verbale karakteristika. Vi oppsummerte i en tidligere artikkel kunnskapsstatus på dette feltet anno 2000. Artikkelen konkluderte med at vurderinger av troverdighet med utgangspunkt i subjektive inntrykk av ikke-verbale signaler var totalt upålitelige - ren sjanse. ${ }^{8}$ Men forskningen fortsetter og hvor står vi nå, 20 år senere?

Forskningen har fremdeles et fokus på løgn i en rettslig sammenheng. Men samfunnsutviklingen har gitt løgnforskningen et utvidet perspektiv. Avsløring av løgn og bedragersk atferd («deception») har blitt et tema i en rekke sammenhenger, fra ansettelse av medarbeidere i bedrifter - avsløre søkere som skryter på seg kompetanse og personlige kvalifikasjoner de faktisk ikke har - til avsløring av asylsøkere som seiler under falsk flagg, utplukking av smuglere ved tollpasseringer, og personer med kriminelle hensikter. Etter de koordinerte flyangrepene på Pentagon og tvillingtårnene i New York, og nedstyrtningen av

\footnotetext{
lengst har oppdaget, M.A. Peters, The history and practice of lying in public, Review of Contemporary Philosophy, 14, s. 46-61, 2015.

${ }^{5}$ Straffeloven $2005 \S 221$ annet ledd.

${ }^{6}$ Straffeprosessloven $\S 128$ første ledd.

${ }^{7}$ Straffeloven $2005 \S 221$ første ledd.

${ }^{8}$ S. Magnussen og U. Stridbeck, Vurdering av troverdighet. Hva sier forskningen? Tidsskrift for Strafferett, 1, s. 8197, 2001.
} 
United Airlines Flight 93, 11. september 2001, ble verden oppmerksom på manglende sikkerhet i kontrollrutinene på flyplasser. Å oppdage våpen og redskaper som kunne brukes som våpen var én ting, men hvordan avsløre potensielle terrorister? Er det mulig å identifisere personer som har noe å skjule gjennom en analyse av de ikke-verbale uttrykkene - kroppsspråket alene? Ville Mohammed Atta, piloten på ett av flyene som krasjet i tvillingtårnene og som er videofilmet mens han sjekker inn, blitt avslørt i en gate-kontroll som fokuserte på analyse av atferd?

\section{Den klassiske løgnforskningen - anno 2020}

Løgn og avsløring av løgn er ikke bare et tema i psykologi-og-jus sammenheng, det er et populært tema som tiltrekker seg medieoppmerksomhet og «eksperter» som forteller oss hva vi skal se etter når vi skal vurdere hvorvidt folk snakker sant eller ikke. I de siste 20 år har vi sett en rekke medieoppslag hvor eksperter påberoper seg kompetanse i løgnavsløring, og forklarer oss hvilke verbale og kroppslige tegn som avslører løgn og bedragersk atferd. Det påfallende i disse oppslagene er at ekspertene kolporterer ideer om sammenhengen mellom kroppsspråk og løgn/sannhet som var tilbakevist av forskningen for 20 år siden. ${ }^{9}$ I et oppslag i det danske magasinet Advokaten i 2012 forteller en kursholder i konsulentbransjen, som også kurser jusstudenter, hvordan Iøgn avsløres i det unnvikende blikk og et urolig kroppsspråk, hvor spesielt urolige ben er kritiske signaler. ${ }^{10}$ I et Dagblad-oppslag fra 2019 kan vi blant annet lese at «et falskt smil peker ofte rett mot ørene, istedenfor oppover mot øynene», "god фyekontakt formidler at du er en troverdig person med mye selvtillit», og «kroppen snakker sannheten

\footnotetext{
${ }^{9}$ S. Magnussen og U. Stridbeck, 2001.

${ }^{10}$ Gjengitt i S. Magnussen, Vitnepsykologi 2.0, s. 201. Abstrakt forlag, 2017
} 
uansett». ${ }^{11}$ Og Advokatenes-HR gjorde i 2018 reklame for et kurs, "Spot a lier», hvor vi får vite at foreleseren, en amerikansk professor i rettsvitenskap (!) "teaches scientifically proven methods to see concealed emotion and detect lies, including how to identify micro-expressions of emotion that last less than a second, recognize when body language reveals lies and when it is meaningless, detect lies in interviews, meetings, investigations, and even over the phone." 12 Og i kursoversikten for 2019 reklamerer Advokatenes-HR for et lignende kurs, i «kunsten å avsløre løgn», der deltakerne skal lære hva «kroppsspråket forteller og hvordan du skal tolke det», denne gangen med en norsk jussprofessor som foredragsholder. ${ }^{13}$

Dette er noe helt annet enn våre litt nedslående konklusjoner i 2001, som nærmest avviste muligheten av å avsløre løgn på grunnlag av atferds-observasjoner. ${ }^{14}$ Hvor har ekspertene sin nyvunne kunnskap fra? Har nyere forskning frembrakt resultater som avkrefter resultatene fra tidligere forskning? For det forskes. Aldert Vrijs standardverk «Detecting lies and deceit» fra 2008 har mer enn 1000 litteraturhenvisninger, ${ }^{15}$ og en større autoritativ oversiktsartikkel fra 2019 identifiserer 206 vitenskapelige artikler publisert i 2016 alene. ${ }^{16,17}$ La oss derfor se hva forskningen de siste 20 år forteller oss, med utgangspunkt i sistnevnte artikkel.

Avsløring av løgn og bedragersk atferd er et forskningsfelt som er preget av svak og fragmentert teori. Lesing av teori og populær pseudovitenskapelig litteratur kan gi et falskt

${ }^{11}$ Magasinet, Dagbladet, 19 oktober, s. 39-42, 2019.

12 http://email.advokatenes-hr.no/t/r-l-jylyhlul-kitjjkjrty-r/

${ }^{13}$ Advokatenes-HR, Kursoversikt, høsten 2019, s. 41.

${ }^{14} \mathrm{~S}$. Magnussen og U. Stridbeck, 2001.

${ }^{15}$ A. Vrij, Detecting lies and deceit. Wiley, Chichester, 2008.

${ }^{16}$ A. Vrij, M. Hartwig og P. A. Granhag, Reading lies: Non-verbal communication and deception. Annual Review of Psychology, 70, s. 294-317, 2019.

${ }^{17}$ Forskningen på løgnavsløring har gjennomgått flere stadier, spesielt forskningen som er relevant i en rettssammenheng, A. Vrij, A paradigm shift in 30 years of deception research, upublisert manuskript, 2019. 
bilde av virkeligheten i dette kunnskapsfeltet, en feilaktig tro på ideer som viser seg lite brukelige i praksis. Det er derfor viktig å fokusere på empiriske studier, hva forskningen faktisk har funnet. Det innledende sitatet av Sigmund Freud kan for de autoritetstro være overbevisende gitt den alminnelige oppfatning av Freuds dype innsikter i menneskets sjelsliv, men Freud står seg, som vi skal se, dårlig i møte med empirisk forskning. Ett nyere eksempel på en forfeilet, men populær teori, er hypotesen om emosjonelle mikrouttrykk. Paul Ekman lanserte i sin tid ideen om at små, raske endringer i ansiktsmuskulatur som er unntatt bevisst kontroll og som er delvis spesifikke for den emosjonelle reaksjon, kan avsløre løgn. ${ }^{18}$ Dette er en besnærende ide, formidlet både av Advokatenes-HR og i Dagbladets 2019 oppslag, ${ }^{19}$ men har ingen som helst empirisk støtte. Det stemmer rett og slett ikke. Større studier av mikrouttrykk analysert i videoopptak finner at disse utgjør kun $2 \%$ av de emosjonelle uttrykk i en ansikt-til-ansikt løgn/sannhet situasjon og dessuten forekommer overveiende hos personer som faktisk snakker sant. ${ }^{20}$ Dessuten, mikroutrykk skal per definisjon ikke være mulig å oppdage i ansikt-til-ansikt situasjoner, de er for små og for raske og kan bare oppdages gjennom detaljanalyser av videoopptak, så de ville uansett være til liten hjelp for avsløring av løgn i dagliglivet. Hypotesen om mikroutrykk som tegn på Iøgn versus sannhet bør umiddelbart skrotes.

\footnotetext{
${ }^{18}$ Se for eksempel P. Ekman, Telling Lies: Clues to Deceit in the Marketplace, Politics and Marriage. New York: W.W. Norton, 1985. Ingen kroppsreaksjoner er spesifikke for løgn. Om noe, er de spesifikke for positiv eller negativ emosjonell aktivering, reaksjoner som i sammenhengen eventuelt kan tolkes som tegn på løgn. Dette gjelder selvsagt også polygraftesten, den såkalte løgndetektor, se S. Magnussen, 2017. Ekmans arbeid har vært sentral inspirasjon for TV-serien Lie to Me, 2009-2011, der "psykologen" Cal Lightman tolket mikrouttrykk og avslørte løgnere i 48 episoder.

${ }_{19}$ Dagbladet, 2019.

${ }^{20} \mathrm{~S}$. Porter og L. ten Brinke, Reading between the lies: Identifying concealed and falsified emotions in universal facial expressions. Psychological Science, 19, s. 508-514, 2008; L. ten Brinke og S. Porter, Cry me a river: Identifying consequences of extremely high-stakes interpersonal deception. Law and Human Behavior, 36, s. 469-477, 2012.
} 
Men hva med de andre mer observerbare kroppslige uttrykk for løgn som Freud alluderer til? Den hittil største metaanalysen av forskningen på verbale og ikke-verbale signaler og deres sammenheng med løgn versus sannferdighet ble publisert av Bella DePaulo og medarbeidere et par år etter vår tidligere artikkel. ${ }^{21}$ Den inkluderte 116 studier som unders $\varnothing$ kte 158 antatte holdepunkter for Iøgn hvorav 102 var ikke-verbale, 50 av disse ble analysert i minst seks studier og det er disse som kan være interessante. Her kom 14 verbale og ikke-verbale holdepunkter opp med statistisk signifikante resultater - ikke så underlig med tanke på størrelsen på utvalgene som ble analysert - men ingen av dem oppnådde en styrke som gjorde dem brukelige i praksis. ${ }^{22}$ Med andre ord, det foreligger ikke pålitelige ikke-verbale tegn på Iøgn. Charles Bond og Bella DePaulo publiserte et par år senere en metaanalyse av forskning på hvor gode vi er til å identifisere løgn versus sannhet, med utgangspunkt i en database med totalt mer enn 25.000 deltagere. Ikke forbausende er resultatene fra denne studien heller ikke spesielt oppmuntrende i en rettslig sammenheng. Den gjennomsnittlige skåre var 54 \% korrekt, det vil si på rent sjansenivå. ${ }^{23}$ Dessuten, deltagerne gjorde det dårligere når de faktisk så personen enn når de bare $\mathrm{h} \emptyset$ rte forklaringen, et interessant resultat i relasjon til prinsippet om umiddelbarhet i bevisførsel i norsk rett. ${ }^{24}$ Forfatterne sammenlignet også prestasjonen til grupper som var

\footnotetext{
${ }^{21}$ B. M. DePaulo, J. I. Lindsay, B. E. Malone, L. Muhlenbruck, K. Charlton, og H. Cooper, Cues to deception. Psychol. Bull. 129, s.74-118, 2003.

${ }^{22}$ Det er en statistisk selvfølgelighet at dersom utvalgene som undersøkes er store nok, vil selv ørsmå forskjeller bli pålitelige. Det kan i enkelte sammenhenger være viktig, som i klimaforskning, men i denne sammenhengen hvor vi er interessert i å kunne vurdere enkelttilfeller, er vi interessert i både hvor hyppig et bestemt holdepunkt forekommer og hvor stor er forskjellen mellom sannferdige og ikke-sannferdige forklaringer når det gjelder tilstedeværelsen av dette holdepunktet. Forekommer det antatte atferds-holdepunktet sjelden eller med noenlunde samme hyppighet i sannferdige og ikke-sannferdige forklaringer, er resultatene lite interessante $i$ en praktisk sammenheng, uansett statistisk signifikans i studier med store utvalg.

${ }^{23}$ C. F. Bond og B. M. DePaulo, Accuracy of deception judgments. Personality and Social Psychology Review, 10, s. 214-234, 2006.

${ }^{24}$ Det er selvsagt en rekke gode argumenter for prinsippet om umiddelbarhet i bevisførsel, som betydningen av kontradiksjon og muligheten til å stille oppfølgingsspørsmål. Men det foreligger også vitnepsykologisk forskning
} 
antatte eksperter I Iøgnavsløring - for eksempel, politietterforskere, psykiatere, intervjuere i rekrutteringsselskaper - og finner at de ikke skårer bedre enn lekpersoner.

Aldert Vrij og medarbeidere oppsummerer forskningen på sammenhengen mellom antatte tegn på løgn og faktisk dokumenterte tegn, og konkluderer at det faktisk ikke er noen sammenheng, i alle fall ikke en sammenheng med en styrke som har noen praktisk betydning. ${ }^{25}$ De populært antatte tegn på løgn - det unnvikende blikk, blunking, selvmanipulering, generelt urolig kroppsspråk og skifte i kroppsstilling, urolige ben - har overhodet ingen sammenheng med hvorvidt avsender faktisk produserer en løgn. Og situasjonen er ikke bedre når det kommer til ikke-verbale språklige signaler. Heller ikke her finner forskningen at uriktige forklaringer er koblet til nølende tale, grammatiske feil, høyt stemmeleie, talehastighet, og latenstid mellom spørsmål og svar, alle foreslåtte og populært formidlede tegn på løgn. Så, i følge Vrij og medarbeidere er vi mer eller mindre der vi var i 2001: “....the nonverbal cues to deceit discovered to date are faint and unreliable and ... people are mediocre lie catchers when they pay attention to behavior."26

Men er vi alle like dårlige til å avsløre løgn? Kognitive ferdigheter er normalfordelt i befolkningen - de fleste av oss ligger rundt et gjennomsnitt, noen få skårer lavt og et tilsvarende antall skårer høyt - så hvorfor ikke en tilsvarende fordeling av evnen til å oppdage løgn? Finnes det noen få personer med en enestående evne til å oppdage løgn, såkalte «lie detection

som synes å utfordre dette prinsippet. Det handler om vurdering av troverdighet. Vi refererer i denne artikkelen forskning som viser at bedømmelser av løgn versus sannhet basert på et vitnes fremtreden er totalt upålitelige, og en rekke andre studier viser at i en ansikt-til-ansikt situasjon påvirkes våre vurderinger av anklagede, fornærmede og vitner av en rekke forhold som intet med troverdighet har å gjøre. S. Magnussen og A. Melinder, Umiddelbarhetsprinsippet i bevisvurdering - en utfordring til rettssikkerheten? Lov og Rett, 53, s. 603-621, 2014, gir en oversikt over denne forskningen.

${ }^{25}$ A. Vrij et al., 2019.

${ }^{26}$ A. Vrij et al., 2019, s. 295. 
wizards» $?^{27}$ Igjen maner forskningen til edruelighet. Metaanalyser av store databaser og senere empiriske oppfølgingsstudier viser at det ikke er systematiske individuelle forskjeller i evnen til å oppdage løgn. ${ }^{28}$ Denne forskningen viser også at det er karakteristika ved avsender som er den viktigste kilden til vurdering av løgn versus sannhet. Noen av oss fremstår som mindre troverdige enn andre, uavhengig om vi lyver eller forteller en sannferdig historie. Hva som karakteriserer «troverdige» og «ikke-troverdige» personer vet vi ikke. Fysiske karakteristika kan spille en rolle, selv om utseende selvsagt ikke har noen sammenheng med faktisk troverdighet. ${ }^{29}$ Uansett, slike funn bidrar til å forklare hvorfor løgnavsløring basert på avsenders fremtreden forblir et rent sjansespill.

Disse nokså overbevisende resultatene er frembrakt gjennom mange års forskning som omfatter et stort antall kreative modellstudier i laboratoriet i tillegg til feltstudier av avhør av kriminelle, analyser av TV-intervjuer med slektninger av ofre som appellerte til drapsmannen om å melde seg, hvorav noen viste seg å være den faktiske gjerningspersonen, og videoopptak av politiintervjuer med personer stoppet i trafikkontroll, hvorav noen hadde en kriminell atferd å skjule. ${ }^{30}$ Forskningen forteller oss at retten ikke kan basere sine avgjørelser på eget inntrykk av vitners troverdighet, ei heller på sakkyndiges vurdering av troverdighet. Dette er et område

${ }^{27}$ C. F. Bond Jr. og A. Uysal, On lie detection "wizards". Law and Human Behavior. 31, s. 109-115, 2007.

${ }^{28}$ C. F. Bond og B. M. DePaulo, Individual differences in judging deception: accuracy and bias. Psychological Bulletin, 134, s. 477-492, 2008.

${ }^{29}$ T. Levine, K. Serota, H. Shulman, D. Clare, H. Park, A. Shaw et al. Sender demeanor: Individual differences in sender believability have a powerful impact on deception detection judgments. Human Communication Research, 37, s. 377-403, 2011; M. K. H. Law, S. A. Jackson, E. Aidman, M. Geiger, S. Olderbak og S. Kleitman, It's the deceiver, not the receiver: No individual differences when detecting deception in a foreign and a native language. PLOS ONE, 13, e0196384, 2018.

${ }^{30}$ S. Mann, A. Vrij, R. P. Fischer og M. Robinson, See no lies, hear no lies: Differences in discrimination accuracy and response bias when watching or listening to police suspect interviews. Applied Cognitive Psychology, 22, s. 10621071, 2008; L. ten Brinke og S. Porter, op. cit., 2012; M. E. Carlucci, N. S. Compo og L. Zimmermann, Lie detection during high-stakes truths and lies. Legal and Criminological Psychology, 18, s. 314-323, 2013. 
hvor det ikke finnes reell ekspertise. Det vil si, ekspertise er å kjenne forskningen og formidle til beslutningstakere resultatene av hva forskningen til enhver tid har funnet. Anno 2020 er det ikke dokumentert verbale eller ikke-verbale tegn på Iøgn versus sannferdighet som med noen grad av pålitelighet kan assistere rettens beslutninger. Når retten i en enkelt sak legger til grunn anklagedes, fornærmedes eller vitners troverdighet slik den fremstår for retten uten at denne vurderingen har klar støtte i andre bevis, står man i fare for både uriktige domfellelser og uriktige frifinnelser. Retten skal foreta en vurdering av bevissituasjonen, av de faktiske bevis og ikke støtte seg på troverdighetsvurderinger basert på aktørenes fremtreden. ${ }^{31}$ Forskningen kan utelukkende vise til enkelte svake tendenser på gruppenivå, som ikke kan anvendes på et individnivå.

En nylig publisert artikkel åpner for ett ørlite mer nyansert bilde av vår manglende evne til å identifisere løgn på grunnlag av ikke-verbal kommunikasjon, hvor et par modellstudier antyder at deltagere som er meget sikre på sin egen vurdering også skårer noe høyere enn deltagere som er mindre sikre. ${ }^{32}$ Dette er et tema som har dukket opp i andre vitne-

\footnotetext{
${ }^{31}$ I utakt med forskningens anbefalinger instruerer dommere i USA retten om å legge vekt på aktørenes ikkeverbale kommunikasjon, A. Vrij et al., op. cit. 2019. Dette har muligens sammenheng med at i USA har politiets etterforskning gjennom mange år vært preget av en avhørsstrategi som tar sikte på å fremkalle en tilståelse hvor avhører i opptakten til avhøret noterer seg den mistenktes kroppsspråk og tegn på nervøsitet og uro - hvem er for $\varnothing v r i g$ ikke nervøse i et politiavhør - og benytter deretter en aggressiv avhørsstrategi med anklager om løgn og skyld, F. E. Inbau, J. E. Reid, J. P. Buckley, og B. C. Jayne, Criminal interrogation and confessions. 5. utgave. Burlington, MA: Jones and Bartlett Learning, 2013. I USA har politiets bruk av den såkalte Reid-teknikken, som er slaktet av forskere, bidratt til et betydelig antall falske tilståelser og feilaktige dommer, og vi snakker her om livstidsdommer, endog dødsdommer, www.innocenceproject.com. I Europa er avhør preget av en informasjonssøkende strategi, A. Griffiths, og A. Rachlew, From interrogation to investigative interviewing. The application of psychology. I A. Griffiths \& R. Milne (red.) The psychology of criminal investigation: Theory into practice, s. $154-178$, London, Routledge, 2018. I motsetning til i USA instruerer dommerne i England retten om ikke å legge vekt på de ikke-verbale signalene, men konsentrere seg om hva som blir sagt, A. Vrij et al., 2019. I Norge foreligger det ingen slik instruksjon eller anbefaling.

${ }^{32}$ A. M. Smith og A. M. Leach, Confidence can be used to discriminate between accurate and inaccurate lie decisions. Psychological Science, 14, s. 1052-1061, 2019.
} 
psykologiske sammenhenger, at særdeles høy subjektiv sikkerhet på egen prestasjon også er koblet til en faktisk pålitelig prestasjon. ${ }^{33}$ Men når det gjelder løgn-avsløring er ikke økningen betydelig. Resultatene viste en $\varnothing$ kning fra sjansenivå til rundt 70 \% korrekt skåre for deltagere som uttrykker meget høy subjektiv sikkerhet på egen vurdering. Så selv for de særdeles sikre deltagerne er rundt hver tredje bedømmelse feil, hvor sjansenivået er hver annen bedømmelse. Og vi kjenner ikke treffsikkerheten i feltstudier. Høy subjektiv sikkerhet på egen vurdering er ikke en pålitelig indikator på korrekt vurdering av løgn versus sannhet på individnivå. ${ }^{34}$

\section{Avsløring av løgn og bedragersk atferd}

Gitt den sosiale og politiske betydning av å kunne identifisere løgn og bedragersk atferd har det blitt lansert en rekke metoder for å identifisere personer som seiler under falsk flagg. Disse metodene synes i liten grad å være basert på fagfellevurdert forskning, men sprunget ut av ideer om tegn på troverdighet som minner mistenkelig om vestens psykologiske folklore. Så hvorledes står metodene seg i møte med forskningen?

Det er særlig to metoder som har fått internasjonal oppmerksomhet og er benyttet i praksis. En større artikkel forfattet av flere enn 40 ledende internasjonale forskere oppsummerer forskningen anno 2019. ${ }^{35}$ Og den er ikke spesielt oppmuntrende for potensielle brukere. Ett

\footnotetext{
33 S. Magnussen, Er sikre øyevitner pålitelige øyevitner? Lov og Rett, 2020, under trykking,

34 Det gjelder ikke bare løgn, det er i det hele tatt vanskelig å bedømme andre menneskers holdninger og intensjoner på grunnlag av ikke-verbale signaler: «Jeg har i hvert fall ett jurymedlem på Pers side. Jeg så det på ham. Han tror på Per Orderud», sa forsvarsadvokaten Cato Schiøtz til statsadvokatene da han peker ut medlemmet TW rett etter at juryen har trukket seg tilbake for å avgjøre skyldspørsmålet. Senere sier jurymedlemmet TW til Dagbladet at han ville sperre ekteparet Orderud inne i 25 år om det var mulig, E. Tumyr og F. Gander, Da døden kom til Orderud, Tanum, 2002, s. 115.

35 Denault, V., Plusquellec, P., Jupe, L. M., St-Yves, M., Dunbar, N. E., Hartwig, M., ... van Koppen, P. J. The analysis of nonverbal communication: The dangers of pseudoscience in security and justice contexts. Anuario de Psicología Jurídica, 30, s. 1-12, 2020.
} 
program, SPOT («Screening of Passengers by Observation Techniques»), basert på israelske metoder, er direkte rettet mot å oppdage mistenkelige personer i sikkerhetskontrollene på flyplasser, og implementert på flere flyplasser i USA. Observatørene blir trenet i og instruert om å se etter et stort antall tegn som kan tyde på at den observerte er en mistenkelig person, som å unngå øyekontakt, se ned, ha på seg klær som virker upassende for anledningen, ha sterk kroppslukt, dekke til munnen med hånden når de snakker, osv. ${ }^{36}$ Hver observasjon varer i ca. 30 sekunder, og ved mistanke kan passasjeren bli holdt tilbake og nektet videre flyvning. Programmet, som overfladisk referer til vitnepsykologisk forskning - Paul Ekman blant annet -har ingen separat forskningsstøtte, men er begrunnet $\mathrm{i}$ et utall populære og pseudovitenskapelige artikler. Vincent Denault og medarbeidere slakter dette programmet med henvisning til vitnepsykologisk forskning, og konkluderer at «current scientific knowledge on nonverbal communication suggests that security and justice professionals should not rely on the observation of behavioral indicators (or combinations of some of them) in face-to-face interactions to detect terrorists". ${ }^{37}$ Og interessant nok, i en nylig publisert, nokså omfattende og realistisk modellstudie av evnen til å oppdage smuglere i tollpasseringer, fant forskerne at observatørene, som fokuserte på atferd og tegn på nervøsitet, skåret litt under sjanse. ${ }^{38}$ Men SPOT synes å overleve, med argumentet at det ikke er kommet flere 9.11 terrorister til USA etter programmet ble innført.

\footnotetext{
${ }^{36}$ V. Denault et al., 2019.

${ }^{37}$ V. Denault et al., 2019, s. 4.

${ }^{38}$ S. Mann, H. Deeb, A. Vrij, L. Hope, og L. Pontigia, Detecting smugglers: Identifying strategies and behaviors in individuals in possession of illicit objects, Applied Cognitive Psychology, online first, 2019..
} 
Det andre programmet, som også har fått utbredelse i Europa, er SYNEROLOGY, et kanadisk atferds-program basert på analyse av kroppsspråk, spesielt gester. Dette programmet, som i særlig grad synes å være rettet mot dommere og advokater med virke i retten, har et mer generelt siktepunkt, nemlig å oppdage løgn og bedragersk atferd i dagliglivet. Programmet påberoper seg å være vitenskapelig begrunnet, uten at det foreligger noe belegg for det, ${ }^{39} \mathrm{og}$ fremsetter en rekke nokså oppsiktsvekkende påstander om sammenhengen mellom observerbar atferd og sinnstilstand. Her får psykologisk folklore herje fritt. Vi kan lese følgende om betydningen av ikke-verbal kommunikasjon: "looking at the hands, following them in all their movements on the face and body seems to be the best way to decipher the emotions and therefore the thoughts of our interlocutor", og at "among the hand movements, micro itching (i.e. "unconscious itching relieved by the tip of the finger or nail)" som foreligger "in embarrassing situations that provoke internal contradictions when we do not allow ourselves what we want, when we censor our words, our attitudes... therefore when we are uncomfortable." Med andre ord, mikrokløe, en pendent til Ekmans mikrouttrykk, opptrer "when there are contradictions between what is said and what is thought". Det stopper ikke her, det er for eksempel "about fifteen ways to touch your nose, with very different interpretations", for ikke å snakke om hva sitteposisjon kan fortelle oss, " a sitting person could be in a position of withdrawal (backward), analysis (backward to the right), escape (backward to the left), stress and discourse control (right), reserve and emotional control (left), attack (forward to the right), flexibility (forward to the left), and interest (forward)". Programmet er også klar på løgn, at “the gap between truth and lies is never completely masked and the body

\footnotetext{
${ }^{39}$ V. Denault et al., 2019.
} 
transmits it" og at løgnere "tends to make two-dimensional gestures, mechanical, disembodied, rather large" fordi "only a person who has really experienced a situation can reproduce it in three dimensions, with gestures sometimes very close to the body and of low amplitude." ${ }^{40}$

Vi har sitert såpass mye fra dette programmet fordi mer enn 3000 kanadiske advokater har gjennomført et treningsprogram i SYNERLOGY, og programmet tilbys nå i Frankrike, Nederland, Spania og Sveits. Den internasjonale forskningsevalueringen av SYNEROLOGY er akademisk nedtonet og sier det ikke foreligger noe vitenskapelig grunnlag for programmets antagelser, ${ }^{41}$ men i klartekst: dette er faktisk det rene tøv.

Hvorfor får slike programmer overleve? Programmene relaterer seg til viktige sosiale spørsmål, som å forhindre terrorisme og identifisere løgn i sosiale og rettslige sammenhenger. Politiske beslutningstakere og de fleste andre adressater til slike programmer etterspør ikke det vitenskapelige grunnlaget for de foreslåtte metodene. Elegante internetsider og pamfletter, overbevisende argumentasjon basert på ideer vi alle er mer eller mindre fortrolige med, og påstander om vitenskapelighet overbeviser beslutningstakere. I en føre-var situasjon implementeres programmer som overhodet ikke fungerer - vi kan ikke vente på vitenskapelig dokumentasjon, er argumentet. ${ }^{42} \mathrm{Jo}$, det er nødvendig å vente på vitenskapelig dokumentasjon. Om ikke annet må beslutningstakere vurdere hvorvidt antagelsene om sammenhengen mellom innsats og forventet resultat - mellom atferdstegn og sannsynlighet for avsløring av bedragersk atferd - kan vitenskapelig begrunnes i hva vi allerede vet. Ikke minst fordi dette også er dyrt.

\footnotetext{
${ }^{40}$ Alle sitatene er hentet fra V. Denault et al., 2019, s. 5-6, som har originalreferanser til kanadiske publikasjoner fra programmet på fransk.

${ }^{41}$ V. Denault et al., 2019.

${ }^{42}$ V. Denault et al., 2019.
} 
USAs myndigheter har for eksempel brukt 1,5 milliarder dollar på et ubrukelig SPOT program i perioden 2007-2015. ${ }^{43}$ Norske myndigheter er prisverdig edruelige.

\section{Avsluttende bemerkninger}

Forskning skal vinne ny innsikt, bringe kunnskapen fremover. Det fremstår som et paradoks at vi i 2020 ikke er kommet videre når det gjelder treffsikkerheten av troverdighetsvurderinger og identifisering av løgnaktige versus sannferdige forklaringer basert på hvorledes folk fremstår. ${ }^{44}$ I beste fall foreligger det svake tendenser til en noe bedre skåre når et stort antall faktorer tas inn i de statistiske analysene ${ }^{45}$ men sosial metrologi er ubrukbar i møte med den enkelte fornærmede, den enkelte mistenkte og det enkelte vitne, og ubrukbar i møte med andre mennesker i dagliglivet og i jobbsammenheng. Det er rett og slett mulig at denne forskningen er en blindgate, at forskerne stiller spørsmål det ikke finnes pålitelige svar på. Ideen som styrer forskningen, at det skulle foreligge lovmessige tegn på løgn/troverdighet som med rimelig sikkerhet kan benyttes i enkelttilfelle, er selv en del av den psykologiske folkloren. Men det sosiale mennesket er mangefasettert, utviser stor individuell variasjon i personlighet og eget uttrykk, er påvirket av individuell historie og kultur, ${ }^{46}$ i tillegg til en myriade av faktorer som

\footnotetext{
${ }^{43}$ V. Denault et al., 2019.

${ }^{44}$ Det foreligger flere foreslåtte nevrovitenskapelige metoder for løgnavsløring, varianter av polygraftester (løgndetektortester) basert på moderne hjerneforskning hvor hjerneaktivitet registreres «on-line» mens personen utfører kognitive oppgaver - for eksempel lyver eller snakker sant. Ingen av disse metodene er i nærheten av et pålitelighetsnivå som gjør dem brukbare i en praktisk sammenheng enten det gjelder jobbintervjuer eller forklaringer under etterforskning av kriminelle forhold, se S. Magnussen, 2017.

${ }^{45}$ M. Hartwig og C. F. Bond, Lie detection from multiple cues: A meta-analysis. Applied Cognitive Psychology, 28, s. 661-676, 2014.

${ }^{46}$ Kulturforskjeller i ikke-verbal kommunikasjon er et nesten fraværende tema i denne forskningen, P. Plusquellec og V. Denault, The 1000 most cited papers on visible nonverbal behavior: A bibliometric analysis. Journal of Nonverbal Behavior, 42, s. 347-377, 2018. I norske saksbehandleres møte med asyls $\varnothing$ kere aktualiseres dette tema. Andre kulturer kan ha et annet kroppsspråk - mer livlig, mindre livlig - og det kan være kulturelle normer som sier at det er uhøflig å se den andre, særlig autoritetspersoner, inn i øynene. I tillegg kommer en mulig selektiv
} 
opererer i de enkelte situasjoner, så det er all grunn til å stille spørsmål ved forskningens utgangspremiss. I tillegg, de aller fleste av de ikke-verbale signaler som har vært lansert som tegn på løgn er under viljemessig kontroll, og når vi alle er fortrolig med de samme ideer om Iøgnaktig atferd, kan vi kontrollere egne reaksjoner i påtvungne tilfelle: Daværende president Bill Clinton flakket ikke med blikket da han på TV benektet sex med Monica Lewinsky, nåværende president Donald Trumps TV-opptredener er heller ikke spesielt preget av et unnvikende blikk, og smuglere på Gardermoen ser nok heller ikke vekk i tollpasseringer. Vi er alle nokså drevne løgnere i dagliglivet.

Gitt de i rettslig sammenheng nedslående resultatene fra mange års forskning - de beh øver for $\varnothing v r i g$ ikke være nedslående i andre sosiale sammenhenger - hva kommer det av at vi gjennom media til stadighet blir fortalt om hvorledes vi kan oppdage løgn, og blir tilbudt kurs som skal gi oss denne kompetansen? Handler det om «die-hard» sosiale stereotypier som gjør oss nærmest impregnert mot forskningskunnskap? Om psykologiske myter som gjenoppdages gang etter gang av begeistrede lesere av pseudovitenskapelig litteratur, aktører som finner en mediepopulær nisje for kurs- og konsulentvirksomhet, uvitende om at det foreligger seriøs forskning som forteller noe helt annet? Det er en mulighet. Forskere advarer i alle fall sterkt mot den voksende pseudovitenskapelige innflytelse i psykologi-og-jus feltet. ${ }^{47} \AA ̊$ være forskningsmessig oppdatert på dette feltet er muligens et urimelig krav å stille til enkeltaktører, til advokater og dommere, for ikke å snakke om oss alle i dagliglivet, men på et systemnivå må

\footnotetext{
hukommelse for hendelser med egen etnisk relevans, N. Anakwah, R. Horselenberg, L. Hope, M. Amankwah-Poku og P. van Koppen, Cross-cultural differences in eyewitness memory reports, Applied Cognitive Psychology, online first, 2020. Troverdighetsvurderinger basert på norsk psykologisk folklore er særdeles lite betryggende.

${ }^{47} \mathrm{~L}$. M. Jupe og V. Denault, Science or pseudoscience? A distinction that matters for police officers, lawyers and judges, Psychiatry, Psychology and Law, online first, 2019.
} 
vi kunne skille mellom skitt og kanel. Juridiske beslutningstakere og kursholdere må forholde seg til forskningsbasert kunnskap.

Vi siterte innledende Sigmund Freud, en forfatter og kliniker som baserte sine teorier på egen erfaring med pasienter. Freud tok feil. Og eksemplet illustrerer hvor nødvendig det er ikke å lytte til autoriteter, men å sjekke hvorvidt empirisk forskning bekrefter eller avkrefter hva autoritetene sier. 